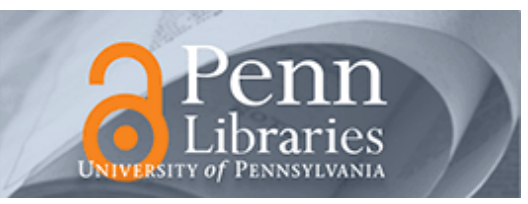

University of Pennsylvania

ScholarlyCommons

July 2000

\title{
Non-Indigenous Bamboo along Headwater Streams of the Luquillo Mountains, Puerto Rico: Leaf Fall, Aquatic Leaf Decay and Patterns of Invasion
}

\author{
Paul J. O'Connor \\ Colorado State University \\ Alan P. Covich \\ Colorado State University \\ Frederick Scatena \\ University of Pennsylvania, fns@sas.upenn.edu \\ Lloyd L. Loope \\ USGS Biological Resources Division
}

Follow this and additional works at: https://repository.upenn.edu/ees_papers

\section{Recommended Citation}

O'Connor, P. J., Covich, A. P., Scatena, F., \& Loope, L. L. (2000). Non-Indigenous Bamboo along Headwater Streams of the Luquillo Mountains, Puerto Rico: Leaf Fall, Aquatic Leaf Decay and Patterns of Invasion . Retrieved from https://repository.upenn.edu/ees_papers/43

Copyright Cambridge University Press. Reprinted from Journal of Tropical Ecology, Volume 16, Number 4, July 2000, pages 499-516.

NOTE: At the time of publication, author Fred Scatena was affiliated with the USDA Forest Service. Currently (June 2006), he is a faculty member in the Department of Earth and Environmental Science at the University of Pennsylvania.

This paper is posted at ScholarlyCommons. https://repository.upenn.edu/ees_papers/43

For more information, please contact repository@pobox.upenn.edu. 


\title{
Non-Indigenous Bamboo along Headwater Streams of the Luquillo Mountains, Puerto Rico: Leaf Fall, Aquatic Leaf Decay and Patterns of Invasion
}

\begin{abstract}
The introduction of bamboo to montane rain forests of the Luquillo Mountains, Puerto Rico in the 1930s and 1940s has led to present-day bamboo monocultures in numerous riparian areas. When a non-native species invades a riparian ecosystem, in-stream detritivores can be affected. Bamboo dynamics expected to influence stream communities in the Luquillo Experimental Forest (LEF) were examined. Based on current distributions, bamboo has spread downstream at a rate of $8 \mathrm{~m} \mathrm{y}-1$. Mean growth rate of bamboo culms was $15.3 \mathrm{~cm} \mathrm{~d}^{-1}$. Leaf fall from bamboo stands exceeded that of native mixed-species forest by $\mathrm{c}$. $30(k=-0.021)$, and leaves from another abundant riparian exotic, Syzygium jambos (Myrtaceae) ( $k=$ -0.018), decayed at relatively slow rates when submerged in streams in fine-mesh bags which excluded macro-invertebrate leaf processors. In a second study, with leaf processors present, bamboo decay rates remained unchanged $(k=-0.021)$, while decay rates of $S$. jambos increased $(k=-0.037)$. Elemental losses from bamboo leaves in streams were rapid, further suggesting a change in riparian zone/stream dynamics following bamboo invasion. As non-indigenous bamboos spread along Puerto Rico streams, they are likely to alter aquatic communities dependent on leaf input.

\section{Comments}

Copyright Cambridge University Press. Reprinted from Journal of Tropical Ecology, Volume 16, Number 4, July 2000, pages 499-516.

NOTE: At the time of publication, author Fred Scatena was affiliated with the USDA Forest Service. Currently (June 2006), he is a faculty member in the Department of Earth and Environmental Science at the University of Pennsylvania.
\end{abstract}




\title{
Non-indigenous bamboo along headwater streams of the Luquillo Mountains, Puerto Rico: leaf fall, aquatic leaf decay and patterns of invasion
}

\author{
PAUL J. O'CONNOR*', ALAN P. COVICH*, F. N. SCATENA $\dagger$ and \\ LLOYD L. LOOPE $\ddagger$
}

*Department of Fishery and Wildlife Biology, Colorado State University, Fort Collins, Colorado 80523, USA

†USDA Forest Service International Institute for Tropical Forestry (IITF), P.O. Box 25000, Rio Piedras, Puerto Rico 00928, USA

$\ddagger$ USGS Biological Resources Division, Haleakalä Field Station, P.O. Box 369, Makawao, HI 96768, USA

(Accepted 8th December 1999)

\begin{abstract}
The introduction of bamboo to montane rain forests of the Luquillo Mountains, Puerto Rico in the 1930s and 1940s has led to present-day bamboo monocultures in numerous riparian areas. When a non-native species invades a riparian ecosystem, in-stream detritivores can be affected. Bamboo dynamics expected to influence stream communities in the Luquillo Experimental Forest (LEF) were examined. Based on current distributions, bamboo has spread downstream at a rate of $8 \mathrm{~m} \mathrm{y}^{-1}$. Mean growth rate of bamboo culms was $15.3 \mathrm{~cm} \mathrm{~d}^{-1}$. Leaf fall from bamboo stands exceeded that of native mixed-species forest by $c$. $30 \%$ over a 10 -mo study. Bamboo leaves $(\mathrm{k}=-0.021)$, and leaves from another abundant riparian exotic, Syzygium jambos (Myrtaceae) $(\mathrm{k}=-0.018)$, decayed at relatively slow rates when submerged in streams in fine-mesh bags which excluded macro-invertebrate leaf processors. In a second study, with leaf processors present, bamboo decay rates remained unchanged $(\mathrm{k}=-0.021)$, while decay rates of $S$. jambos increased $(\mathrm{k}=-0.037)$. Elemental losses from bamboo leaves in streams were rapid, further suggesting a change in riparian zone / stream dynamics following bamboo invasion. As non-indigenous bamboos spread along Puerto Rico streams, they are likely to alter aquatic communities dependent on leaf input.
\end{abstract}

KEY WORDS: bamboo, Bambusa spp., biological invasion, leaf decay, leaf fall, nonindigenous, Puerto Rico, riparian, Syzygium jambos, tropical headwater streams

\footnotetext{
' Current address: National Park of American Samoa, Pago Pago, American Samoa 96799, USA.
} 


\section{INTRODUGTION}

Non-indigenous species are homogenizing the world's biota at a rapidly increasing rate (Vitousek et al. 1996). Biological introductions can develop into monocultures, alter nutrient regimes, and even drive native species to extinction (Ruesink et al. 1995). Biological invasions have been documented as disrupting communities only where and when effects were severe and readily observable, or were directly influencing species loss (Mooney \& Drake 1986, Pimm et al. 1995, but see Vitousek 1990). However, the majority of introductions may be neither direct in influence, nor temporally obvious, and can lead to loss of ecosystem function through indirect effects (Lodge et al. 1998). When an invasion involves a group unrepresented in the native system, communities and ecosystems may be readily altered (Vitousek 1986). In this paper, we consider the impacts of introduced bamboos in headwater rain forest riparian areas of Puerto Rico.

Partly as a result of physical heterogeneities in lotic systems, stream riparian communities possess structural and species compositional diversity (Covich 1988, Gregory et al. 1991). Nevertheless, riparian zones are also common corridors for spread of exotic plants (Naiman \& Décamps 1997). Riparian plants restrict sunlight and primary production within the channel, but along forested headwater streams riparian leaf inputs provide energy sources for stream food webs (Vannote et al. 1980). Leaves deposited in streams can also be critical determinants of community structure by creating heterogeneous microhabitats for invertebrates (Cummins et al. 1989, Friberg \& Winterbourn 1997). This terrestrial-aquatic linkage may be more pronounced in the tropics, where total leaf fall tends to exceed that of temperate forests (Benson \& Pearson 1993).

In both tropical and temperate headwater streams, mixed species leaf fall is important in providing diverse sources of energy and benthic habitat structure (Dudgeon 1994, Irons et al. 1988, Wallace et al. 1997). In contrast, bamboos often form mono-specific stands in riparian zones (Chou 1981, Gadgil \& Prasad 1984). Once established, bamboo can effectively exclude other plant species (Taylor et al. 1996). Similar to such replacement of diverse native forest by bamboo monocultures, disturbances which change the rate or quality of inputs to a stream often affect shifts in detritivores at several trophic levels in the aquatic web (Dudgeon 1994, Molles 1982, O’Connor 1998, Wallace et al. 1997).

Although the worldwide distribution of bamboo has been greatly modified by human intervention, little is understood about bamboo ecology (McClure 1993). The introduction of bamboo to the Caribbean National Forest (contiguous with the Luquillo Experimental Forest) in northeastern Puerto Rico in the 1930s and 1940s (White \& Childers 1945), has led to expanding bamboo monocultures in several riparian areas. Since introduction, the bamboos have spread by vegetative reproduction through extensive rhizome networks, downslope transport and re-rooting of broken culms, and in 1996, by 
flowering and seed-set for the first time on record (P. O'Connor and F. Wadsworth, pers. obs.). We provide the first study of bamboo ecology in Puerto Rico, and describe selected bamboo dynamics expected to affect aquatic consumers in Luquillo's tropical montane watersheds. Leaf fall rate, growth of rhizomally reproduced bamboo culms, spread of bamboo in a headwater riparian zone, and aquatic leaf decay including elemental loss are examined. We compare bamboo leaf decay and elemental loss rates in headwater streams to those of another common LEF riparian exotic, Syzygium jambos Alston (Myrtaceae). In a smaller scale decomposition study we also compare bamboo and $S$.jambos leaf decay rate to that of an LEF native, Guarea guidonia Sleumer (Meliaceae).

\section{STUDY SPECIES}

Most bamboo species (Gramineae) introduced to the Luquillo Experimental Forest (LEF) are in the tropical Asian genus Bambusa (Bambusa vulgaris Schrader ex Wendland, B. longispiculata Gamble ex Brandis, B. tulda Roxb. and B. tuldoides Munro) (White \& Childers 1945). Individuals of another tropical Asian species, Dendrocalamus strictus Nees, were also planted (L. Clark and F. Wadsworth, pers. comm.). Although bamboo was planted along roads to stabilize downhill slopes (White \& Childers 1945), during major disturbances like hurricanes, extensive bamboo root systems can result in catastrophic slope failures when undercut (P. O'Connor, pers. obs.). Coinciding with low stream water levels, B. vulgaris and $D$. strictus can drop their leaves during drought. In their native ranges in Asia, these bamboos usually form secondary forests following shifting agriculture or other disturbances. Climate and soils are often considered primary factors in limiting bamboo productivity (Farrelly 1984, Numata 1979). Constant warm temperatures, high humidity, and evenly distributed rainfall in the LEF means that bamboo may have few natural barriers to expansion besides soil suitability. In coastal rain forests of Brazil, introduced Bambusa spp. and Dendrocalamus spp. dominate large regions with similar climate to the LEF (Numata 1979).

Leaf anatomy and growth patterns are similar among the five bamboo species introduced throughout the LEF (Soderstrom \& Calderón 1979). All form clumps of culms on the landscape, with stalks reaching mature heights of 10 $20 \mathrm{~m}$. These similarities, in conjunction with their highly mixed distributions and the difficulty of identifying bamboo species without flowers or welldocumented planting locations justify our combined treatment of the five bamboo species in this study as 'bamboo'. For comparison with aquatic leaf decay parameters of bamboo, we also examined leaves of Syzygium jambos (rose apple, jamrose), another exotic species forming riparian monocultures in the LEF. On Réunion Island in the Indian Ocean, S. jambos has invaded all streams on the humid coast, and excludes native plants, probably through allelopathy (C. Lavergne, pers. comm.). In several areas of the Luquillo mountains, the current riparian distribution of $S$. jambos can equal that of bamboo. In our second 
and smaller scale decay study we included leaves of Guarea guidonia as a native species comparison. G. guidonia, a dicot, is common along the study reach on Olga stream at $c .200 \mathrm{~m}$ elevation.

\section{METHODS}

We focused on bamboo populations in and adjacent to the Bisley watersheds area of the National Science Foundation's Luquillo Experimental Forest (LEF) Long Term Ecological Research (LTER) site $\left(18^{\circ} 30^{\prime} \mathrm{N}, 65^{\circ} 82^{\prime} \mathrm{W}\right)$. The Bisley watersheds are within a windward, subtropical wet-forest life zone dominated by secondary tabonuco (Dacroydes excelsa Vahl) type forest (Ewel \& Whitmore 1973), and receive a mean annual rainfall of $3500 \mathrm{~mm}$ (Scatena \& Larsen 1991). Terrain is steep, and characterized by high gradient stream channels and narrow drainage divides (Scatena \& Lugo 1995). Headwater streams in Bisley have a highly variable hydrology in response to frequent rainfall events. Stream pools dominate habitats for aquatic macro-invertebrates. The native riparian forest has a diverse community structure, including herbaceous layers, ferns, and several layers of tree canopy which overhang stream channels. Bamboo will also overhang channels, however bamboo monocultures are noticeably simple in comparison to native LEF riparian forest because they lack an understorey, and have a dense ground layer of leaf litter.

\section{Vegetative reproduction and culm growth in bamboo}

Ten culms from vegetatively reproducing bamboo clumps along the Bisley road were randomly selected and measured daily during July-August 1996. Standard diameter (DBH) tapes and telescoping poles were used to determine daily growth rates. Daily through fall $(\mathrm{mm})$ was collected in two nearby ground gauges and compared with growth rates.

\section{Bamboo range expansion}

We surveyed $750 \mathrm{~m}$ of Bisley 3, a representative second-order headwater stream draining 35 ha in the Bisley watersheds. Locations of bamboo clumps within $5 \mathrm{~m}$ of the channel were mapped in reference to the planted source population on the Bisley road. An annual rate of downstream range expansion for bamboo was extrapolated. Total number of culms and mean culm DBH in each clump were used to estimate relative times since clump establishment.

\section{Leaf fall}

To compare rates at which leaves enter streams, a total of 24 plastic baskets with $0.25 \mathrm{~m}^{2}$ openings were lined with fibreglass screening and randomly set at ground level in three plots under bamboo monocultures, and in three plots under adjacent native tabonuco-type forest within the Bisley watersheds. Litterfall was collected biweekly, from 20 August 1996 to 13 May 1997. Collected 
materials were oven-dried at $65^{\circ} \mathrm{C}$ to constant weight and sorted. Dry weights of fallen leaves are reported as $\mathrm{g} \mathrm{m}^{-2} \mathrm{~d}^{-1}$.

\section{Bamboo leaf chemical analyses}

Elemental concentrations in the bamboo leaf fall were determined. Chemical analyses were performed at the USDA Forest Service International Institute of Tropical Forestry laboratory in Río Piedras, Puerto Rico, following methods described in Scatena et al. (1996). Dried leaves were weighed to the nearest 0.1 $\mathrm{g}$ and ground with a Wiley mill through a $0.85-\mathrm{mm}$ stainless steel wire sieve. After digestion with $30 \% \mathrm{H}_{2} \mathrm{O}_{2}$ and concentrated $\mathrm{HNO}_{3}$, samples were analysed with a Beckman Spectra Span V plasma emission spectrometer for P, K, Ca, $\mathrm{Mg}, \mathrm{Al}, \mathrm{Mn}$ and $\mathrm{Fe}$ content. Nitrogen, $\mathrm{C}$ and $\mathrm{S}$ were analysed by dry combustion in a LECO CNS-2000. Carbon $\left(\right.$ as $\left.\mathrm{CO}_{2}\right), \mathrm{S}\left(\right.$ as $\left.\mathrm{SO}_{2}\right)$ and $\mathrm{N}\left(\right.$ as $\left.\mathrm{NO}_{2}\right)$ were determined by infrared and thermal conductivity cells.

\section{Leaf decay in streams}

Two experiments to investigate the decay rates of bamboo and $S$. jambos leaves were carried out. The first, from June-August 1996, assessed leaf decay rates attributed to microbial and chemical processes. We used three accessible headwater streams in or adjacent to the Bisley watersheds (Bisley 3, Bisley 5 and Olga) with pools large enough to receive 70 treatment leaf packs. Because pools are typical leaf deposition sites, and important habitat for leaf processors, packs were submerged in a randomly selected pool in each stream. Four-gram leaf packs of freshly picked, oven-dried bamboo or $S$. jambos leaves were enclosed within $1-\mathrm{mm}^{2}$ mesh bags. The fine-mesh excluded macroinvertebrates and prevented particle loss due to stream flow. Five sets of seven bamboo packs, and five sets of seven $S$. jambos packs, were submerged with each set randomly assigned to a PVG pole secured in pool substrata. A total of 210 leaf packs (two species $\times$ five replicates $\times$ seven samples $\times$ three streams), was placed in the streams. A first sample was collected $72 \mathrm{~h}$ after submergence, to quantify mass loss due to solute leaching. A randomly selected pack was removed from each pole (for a total of five bamboo leaf packs, and five $S$. jambos leaf packs) once a week from each of the three pools for $6 \mathrm{wk}$, beginning $1 \mathrm{wk}$ after submergence. Packs were carefully rinsed in the laboratory to remove accumulated sediments and then leaves were oven-dried at $65^{\circ} \mathrm{C}$ to constant weight, and weighed to the nearest $0.01 \mathrm{~g}$. Daily decay rates were determined using decay constants (k) from negative exponential models (Petersen \& Cummins 1974). Differences were analysed by ANOVA using SAS (1996). Leaves from this decay experiment, and oven-dried samples of freshly picked bamboo and $S$. jambos leaves were analysed for elemental concentrations following the same methods we used for elemental analyses of leaf fall.

The second decay study was conducted in January-February 1997. Only one 
stream (Olga) was used during this second experiment because of the similarity in decay patterns observed across the three streams in the first study, and increased washout probability from unsettled weather patterns prior to this experiment. Leaves of bamboo, S. jambos and Guarea guidonia were decomposed without mesh bags to allow access to the leaves by macro-invertebrates. A total of 84 (three species $\times$ four replicates $\times$ seven samples) 4 -g oven-dried leaf packs secured within tension clips was submerged in a headwater pool of Olga stream. As in the earlier experiment, packs rested on the bottom. Because no mesh bags were used, leaf fragments may have been broken off by stream flow as decay advanced. Samples were collected at the same intervals as in the first decay experiment, and similarly dried and weighed. Decay constants were analysed by analysis of variance (ANOVA) and differences among species were compared by least significance difference (LSD) using SAS (1996).

\section{RESULTS}

Vegetative reproduction and culm growth in bamboo

Culm growth rates increased over time during our sampling period. Diameter at breast height (DBH) of growing culms did not change over time. Vertical growth was rapid, with a mean growth rate of $15.3 \mathrm{~cm} \mathrm{~d}^{-1}$. We found no apparent relationship between throughfall and growth (Figure 1). Daily growth minima for 50\% of culms was during Hurricane Bertha on 9 July 1996.

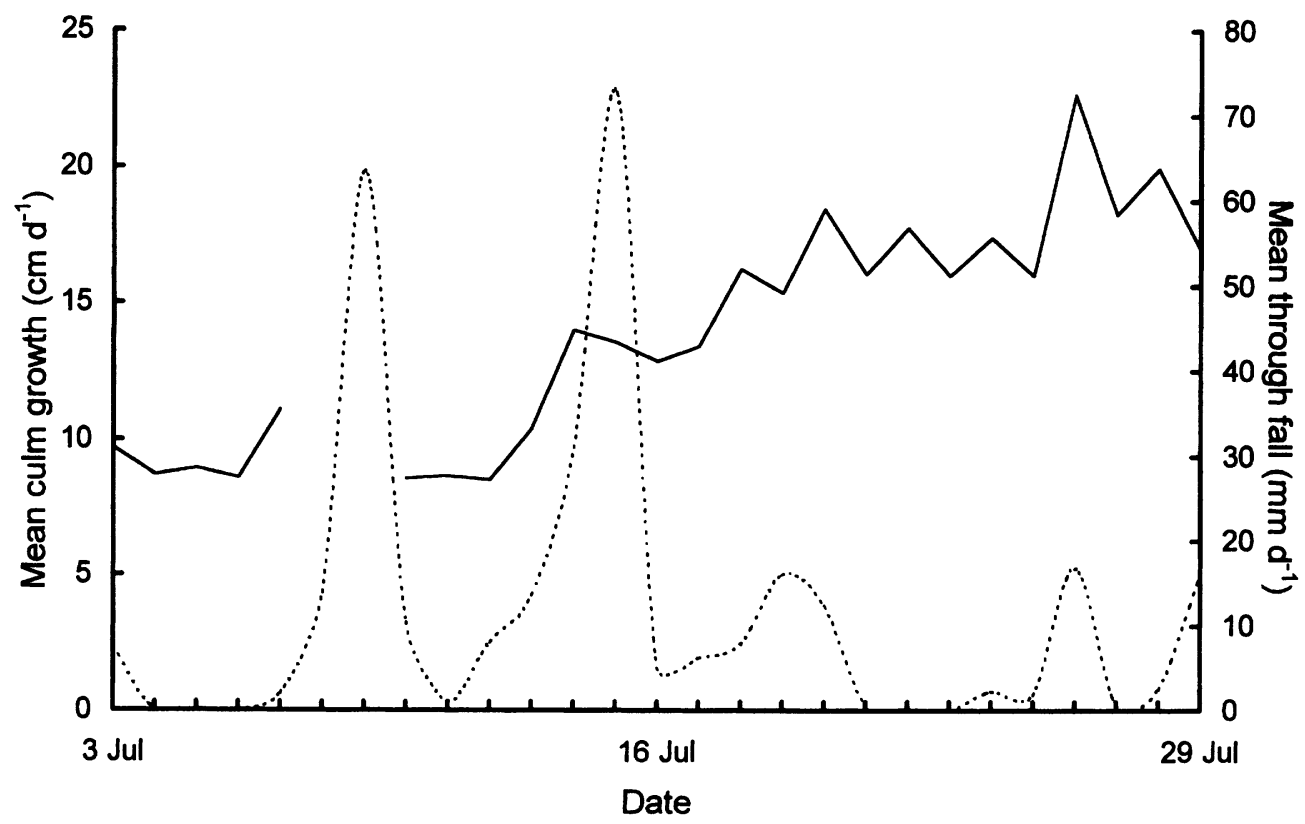

Figure 1. Comparison of mean culm growth rates of bamboo along the Bisley road (solid line), to daily throughfall rates (fine-dashed line) during July 1996, Luquillo Experimental Forest, Puerto Rico. 
Downstream spread of bamboo

Bamboo clumps occurred along Bisley 3 until $430 \mathrm{~m}$ downstream from their original planting site on the Bisley road. Using 1945 as the average planting year, the bamboos have spread at an approximate rate of $8 \mathrm{~m} \mathrm{y}^{-1}$. Logistic regression revealed a relationship between mean culm DBH and number of culms per clump $(r=0.856)$. No linear relationship was found between downstream distance from the Bisley road and size of bamboo clumps (Figure 2). The shortest distance between consecutive clumps occurred in a low-gradient reach, 170-194 $\mathrm{m}$ downstream of the road.

\section{Leaf fall}

From August 1996 to May 1997, mean leaf fall was $1.62 \mathrm{~g} \mathrm{~m}^{-2} \mathrm{~d}^{-1}$, for branches and $1.10 \mathrm{~g} \mathrm{~m}^{-2} \mathrm{~d}^{-1}$ for mixed-species native forest. For the first $2 \mathrm{mo}$ of this period leaf fall rates of bamboo exceeded those of mixed species forest in every sample collected (Figure 3 ). Concentrations of nutrients considered important to stream communities $\left(\mathrm{mg} \mathrm{g}^{-1}\right)$ were lower in bamboo than in native forest leaf fall (Figure 4).

\section{Leaf decay in streams}

Bamboo and $S$. jambos leaves enclosed in mesh bags decayed at similar rates (Figure 5). Negative exponential models and negative linear models to the

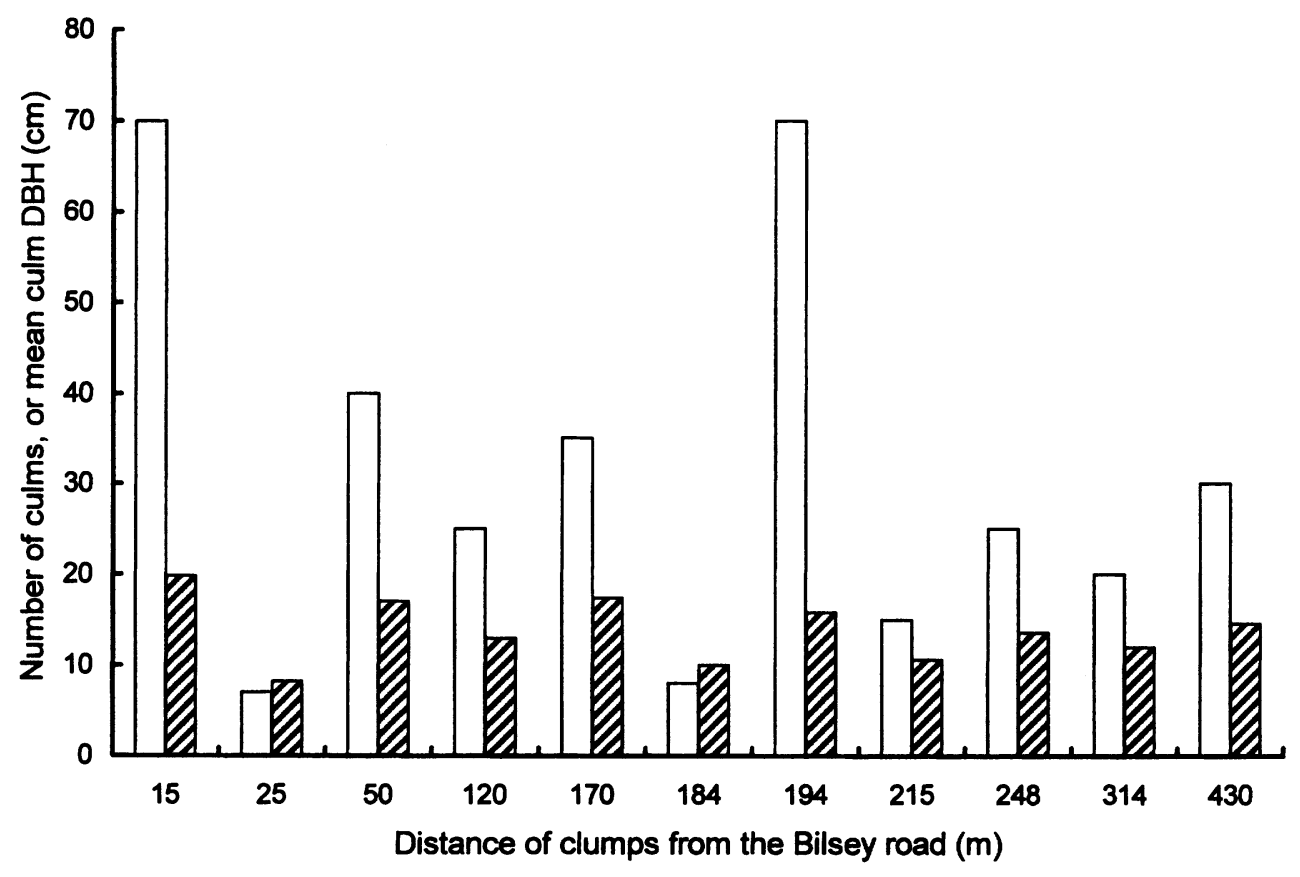

Figure 2. Changes in clump size with downstream distance, based on two measures (culms per clump, open bars; mean culm DBH, hatched bars), within a 5-m buffer zone of the Bisley 3 stream channel, Luquillo Experimental Forest, Puerto Rico. 


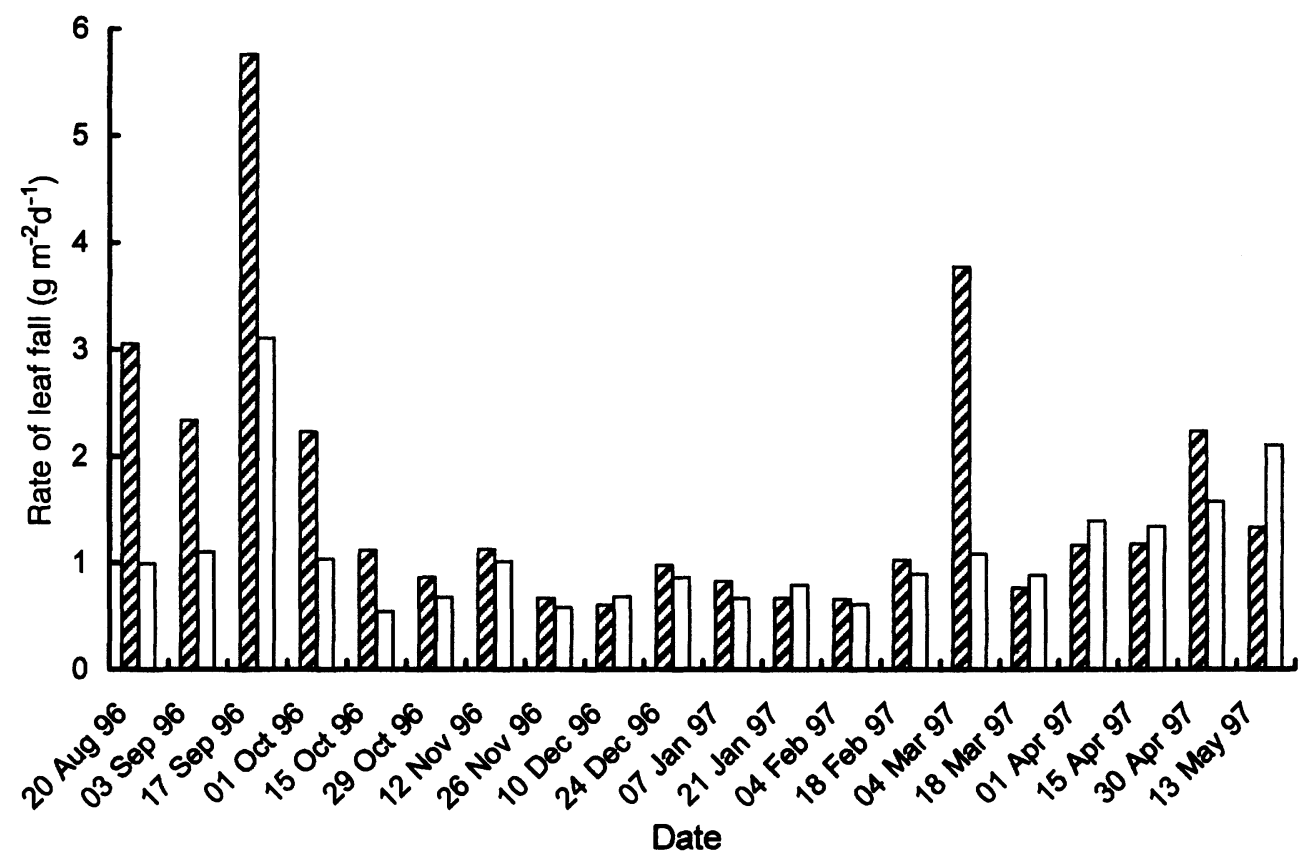

Figure 3. Mean daily leaf fall rates under bamboo (hatched bars) and mixed native forest stands (open bars) in the Bisley watersheds from August 1996 to May 1997, Luquillo Experimental Forest, Puerto Rico.

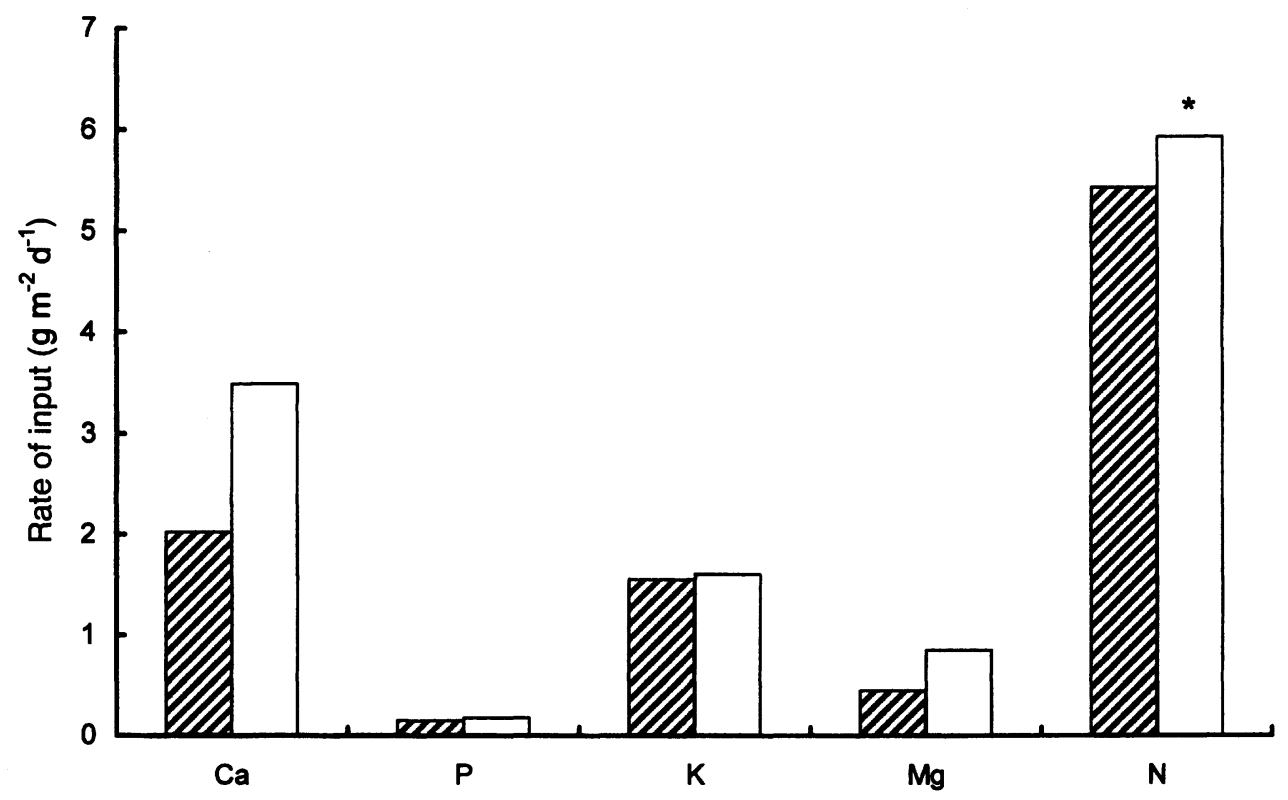

Figure 4. Input rates of selected elements in leaf fall within bamboo (hatched bars), and native mixed (open bars) forest stands in the Bisley watersheds, Luquillo Experimental Forest, Puerto Rico. *, native forest leaf fall $\mathrm{N}$ from non-hurricane leaf fall from Lodge et al. (1991). 
decay data provided similar fits of $r^{2}>0.98$. Decay constants $(k, \pm$ SE) from the exponential models were $-0.021 \pm 0.002$ for bamboo, and $-0.018 \pm 0.001$ for $S$. jambos. Decay constants did not differ between the two leaf types when decomposed in fine-mesh bags. Daily weight losses as described by linear models were $-0.052 \pm 0.004 \mathrm{~g} \mathrm{~d}^{-1}$ for bamboo, and $-0.051 \pm 0.002 \mathrm{~g} \mathrm{~d}^{-1}$ for $S$. jambos.

In the second decay study, decay constants (k) for unbagged bamboo leaves (negative exponential model $\left.\mathrm{r}^{2}>0.95\right)$ were unchanged $(-0.021 \pm 0.002)$ from those in bags, but increased to $-0.037 \pm 0.003$ for leaves of $S$. jambos (Figure $5)$. Decay rates were similarly approximated by linear models $\left(\mathrm{r}^{2}>0.95\right.$ for bamboo; $r^{2}>0.97$ for $S$. jambos), and weight losses using these models were $-0.054 \pm 0.004 \mathrm{~g} \mathrm{~d}^{-1}$ for bamboo and $-0.075 \pm 0.003 \mathrm{~g} \mathrm{~d}^{-1}$ for $S$. jambos. Leaves from the native tree species Guarea guidonia followed only a negative exponential model $\left(\mathrm{r}^{2}>0.99\right)$, with $\mathrm{k}=-0.040 \pm 0.003$ (Figure 5). Rates among species differed significantly $(\mathrm{F}=15.10 ; \mathrm{df}=2,9 ; \mathrm{P}<0.010)$. The LSD multiple comparison $(\alpha=0.05, n=4)$ revealed that decay rates of bamboo leaves (mean $\mathrm{k}=0.021$ ) were significantly slower than those of $S$. jambos (mean $\mathrm{k}=0.037$ ) and G. guidonia (mean $\mathrm{k}=0.040$ ). Decay rates for the latter two species were not significantly different.

Nutrient dynamics of leaves in streams

Elemental mobility from decaying bamboo leaves during the first $3 \mathrm{~d}$ were, in decreasing order of percentage loss, $\mathrm{K}, \mathrm{Ca}, \mathrm{P}, \mathrm{N}$ and $\mathrm{C}$. After $6 \mathrm{wk}$, elemental concentrations in bamboo leaves were, in decreasing order, C, N, P, Ca and $\mathrm{K}$ (Figure 6) (Table 1). In $S$. jambos, elemental mobility, beginning with greatest initial loss over the first $3 \mathrm{~d}$ were, in decreasing order, $\mathrm{K}, \mathrm{P}, \mathrm{N}, \mathrm{C}$ and Ca. After 6 wk, highest elemental concentrations in $S$. jambos were, in decreasing order, Ca, N, C, P and K (Figure 6) (Table 1). Large increases in metal concentration occurred in leaves of both species (Table 1). Fresh bamboo leaves had higher $\mathrm{Al}, \mathrm{Fe}$ and $\mathrm{Mn}$ concentrations than fresh $S$. jambos leaves.

\section{DISCUSSION}

Rain forests of northeast Puerto Rico are held in stages of intermediate succession by disturbance events such as hurricanes, landslides and frequent stream spates (Covich et al. 1996, Lugo \& Scatena 1996). As a result, the LEF contains naturally species-diverse systems, a characteristic strongly reflected in its riparian zones (Reagan \& Waide 1996). If an exotic monoculture does not differ structurally from a native forest, it may not necessarily disrupt community functions (Lugo 1992). Bamboo and its leaves, however, clearly possess influential characteristics among forest communities and leaf inputs to streams in the LEF.

\section{Rhizome reproduction and culm growth in bamboo}

Growth of bamboo culms in the LEF was typical of bamboo in other regions in that culm DBH did not change with increasing height (Christianty et al. 
(a) With bags

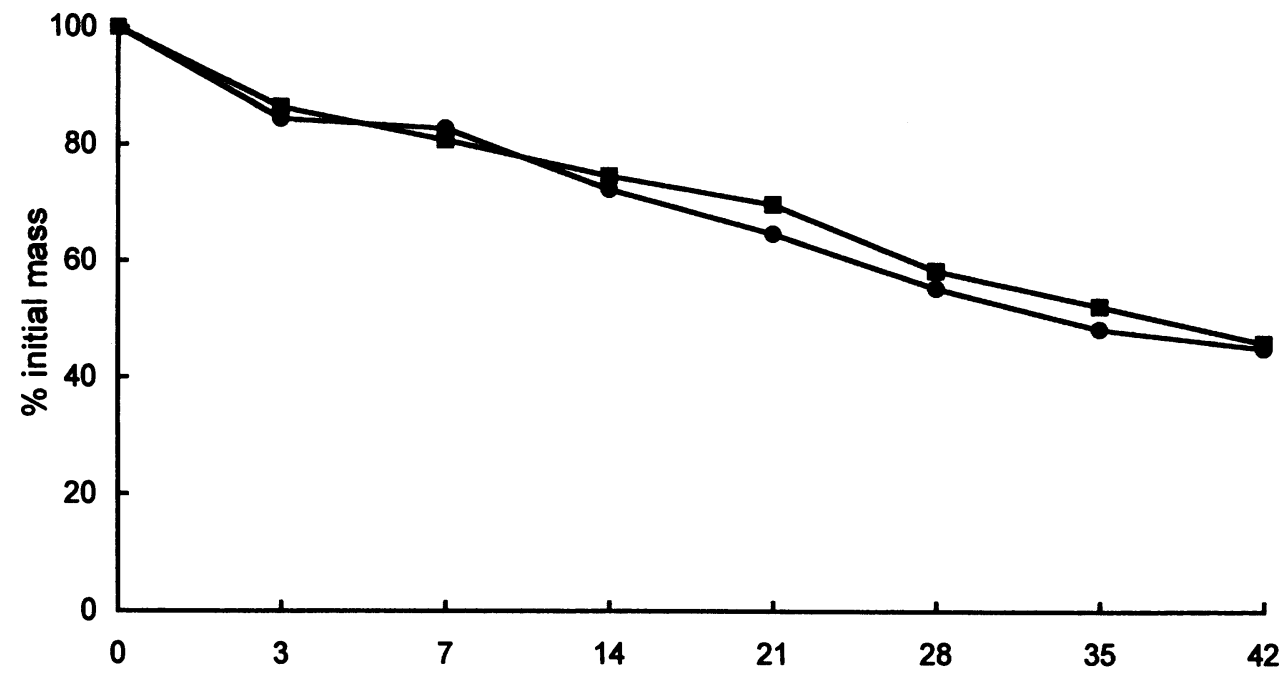

(b) Without bags

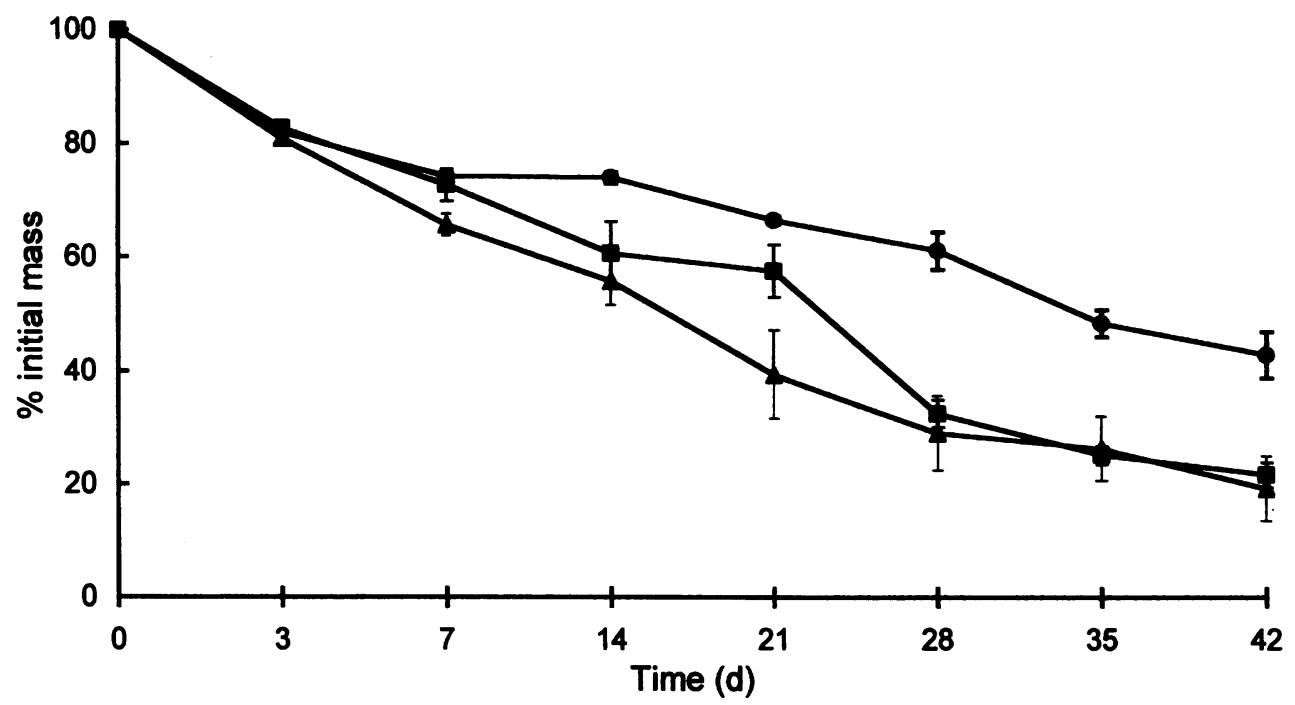

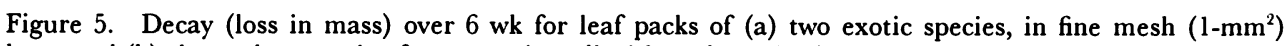
bags, and (b) these plus a native forest species, all without bags, in three headwater streams in the Luquillo Experimental Forest, Puerto Rico. Symbols for species: Bamboo (๑), Syzygium jambos (ם) and Guarea guidonia $(\Delta)$. In $(a)$, the SEs of the means $(n=15)$ were too small to be visible on the graph; they ranged from 0.01 to 0.04 for bamboo, and from 0.01 to 0.02 for $S$. jambos; in (b) the SEs are based on means with $n=4$.

1996). At a mean growth rate of $15.3 \mathrm{~cm} \mathrm{~d}^{-1}$ in height, the culms we measured attained mature heights of $10-20 \mathrm{~m}$ in $c .4$ mo. Because rainfall in the LEF is distributed fairly evenly throughout the year (Scatena \& Larsen 1991), culm production and growth may occur on a continual basis. Regression of daily 
(a) Bamboo

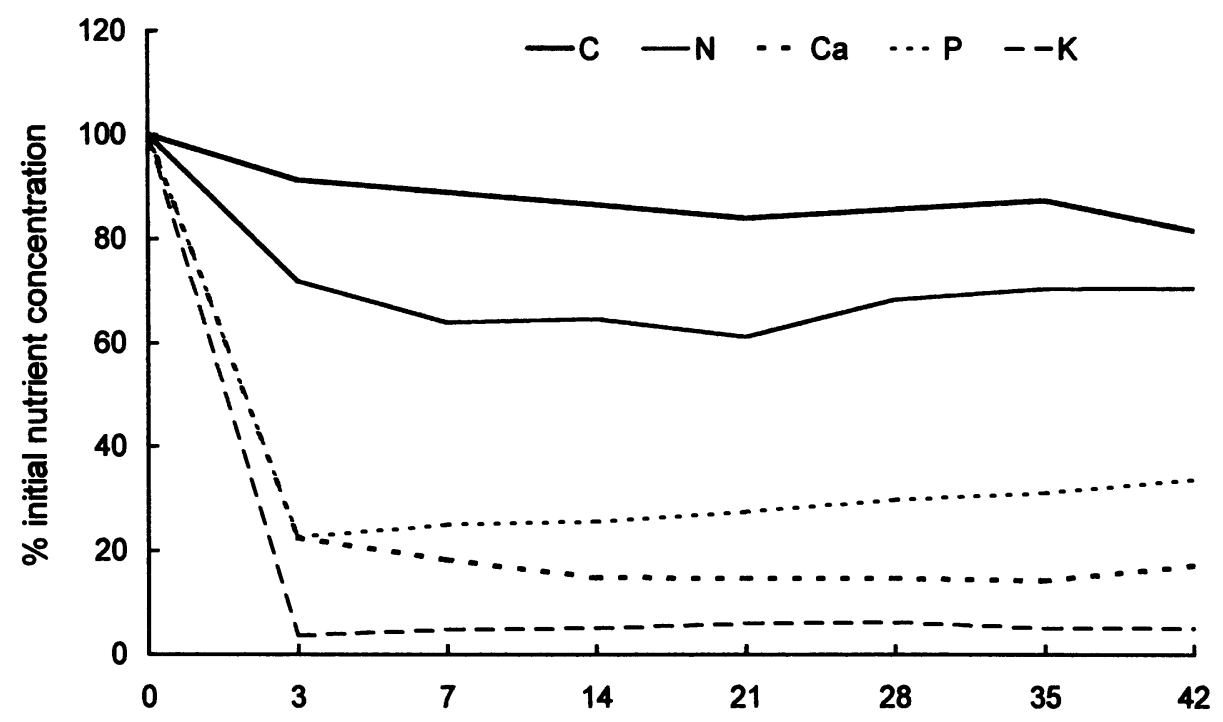

(b) S. jambos

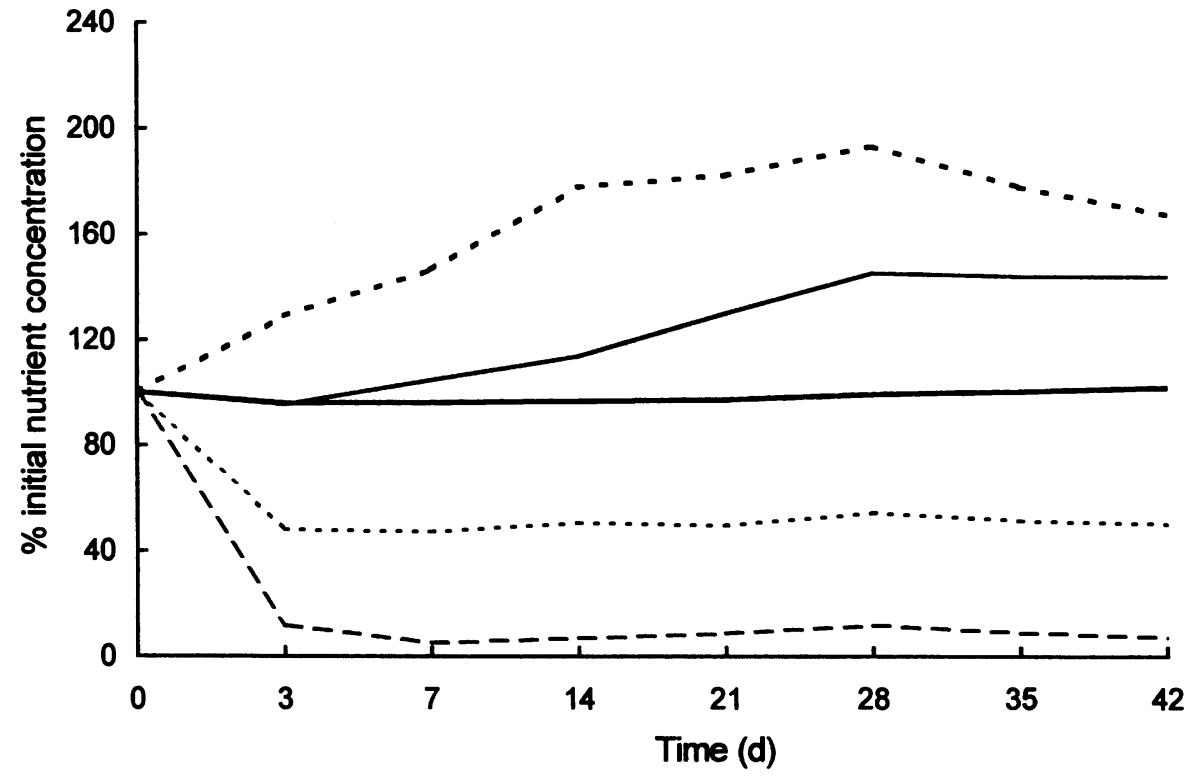

Figure 6. Changes in mean concentrations of selected elements $(n=15)$ in (a) bamboo leaves and (b) leaves of Syzygium jambos, over 6 wk of decay in three headwater streams from June-August 1996, Luquillo Experimental Forest, Puerto Rico. 
Table 1. Initial concentrations $\left(\mathrm{mg} \mathrm{g}^{-1}\right)$ of selected elements in green leaves of exotic riparian trees, and mean percentages of initial concentration remaining in the leaves $(\% \pm 1 \mathrm{SE})$ after 6 wk of aquatic decay in Luquillo Experimental Forest headwater streams, Puerto Rico.

\begin{tabular}{lccccc}
\hline & \multicolumn{2}{c}{ Initial concentration $\left(\mathrm{mg} \mathrm{g}^{-1}\right)$} & & \multicolumn{2}{c}{ \% remaining after 6 wk } \\
\cline { 1 - 2 } \cline { 5 - 6 } Element & Bamboo' & Syzygium jambos & & Bamboo' & Syzygium jambos \\
\hline $\mathrm{Ca}$ & 8.16 & 6.65 & & $17.21 \pm 2.57$ & $167.39 \pm 9.21$ \\
$\mathrm{P}$ & 0.93 & 0.75 & & $33.80 \pm 8.99$ & $50.35 \pm 2.54$ \\
$\mathrm{Mg}$ & 1.51 & 3.22 & & $82.12 \pm 34.97$ & $47.63 \pm 3.65$ \\
$\mathrm{~K}$ & 12.09 & 8.06 & & $5.11 \pm 0.73$ & $7.10 \pm 0.31$ \\
$\mathrm{C}$ & 456.55 & 532.70 & & $81.50 \pm 4.75$ & $101.81 \pm 0.13$ \\
$\mathrm{~S}$ & 4.76 & 1.97 & & $3.94 \pm 0.36$ & $93.31 \pm 2.53$ \\
$\mathrm{EN}$ & 24.20 & 14.40 & & $70.52 \pm 4.74$ & $144.11 \pm 2.23$ \\
$\mathrm{Mn}$ & 1.01 & 0.02 & & $18.14 \pm 5.18$ & $650.77 \pm 23.68$ \\
$\mathrm{Al}$ & 0.94 & 0.07 & & $769.99 \pm 122.97$ & $1443.15 \pm 359.05$ \\
$\mathrm{Fe}$ & 0.55 & 0.05 & & $1327.02 \pm 313.02$ & $4525.23 \pm 448.26$ \\
\hline
\end{tabular}

'Bamboo is used to generally refer to leaves from five possible species of bamboos (Bambusa vulgaris, B. tulda, $B$. longispiculata, $B$. tuldoides and Dendrocalamus strictus).

growth rates on through fall showed no strong correlation with culm growth, however as is visible in Figure 1, growth rates were greater during decreased through fall following several heavy rain events early in the measured growth period. Half of the culms registered daily growth minima during Hurricane Bertha (9 July 1996), supporting an observation by Numata (1979), that winds can cause excessive transpiration contributing to a slowing of growth.

\section{Downstream spread of bamboo}

Distribution of bamboo along the Bisley 3 stream revealed that bamboo spread in LEF riparian zones is a stochastic process which does not lend itself easily to invasion modelling efforts (see Hastings 1996). A greater count and mean $\mathrm{DBH}$ of culms within a bamboo clump is expected to reflect a longer time since clump establishment. If bamboos were proceeding downstream in a predictable manner, we would expect to find the smallest clumps furthest from the source population. However, there was no correlation between clump size and distance from the source population. Bamboo clumps were found as far as $430 \mathrm{~m}$ downstream from the Bisley road, and the largest clumps were at $15 \mathrm{~m}$ and $194 \mathrm{~m}$ downstream. Bamboo spread is likely to be a function of complex disturbance events such as high flows and hurricanes. High stream flows and winds may dislodge or break upstream culms, which can re-root downstream. A lack of planting records precludes an exact model of spread, but we offer 8 $\mathrm{m} \mathrm{y}^{-1}$ as an estimated maximum annual rate of downstream range expansion.

\section{Leaf fall}

Leaf fall patterns determine rates at which energy or habitat structure may be available for benthic stream fauna. Leaf fall rates $\left(\mathrm{g} \mathrm{m}^{-2} \mathrm{~d}^{-1}\right)$ in bamboo plots exceeded those in nearby native forest plots by c. $30 \%$. Extrapolating our results to a period of an entire year suggests that annual bamboo leaf fall in the LEF would total $5877 \mathrm{~kg} \mathrm{ha}^{-1}$. This total is within a range of recently 
Table 2. Recently reported bamboo leaf fall rates.

\begin{tabular}{lcccc}
\hline Species & Location & Status & Leaf fall $\left(\mathrm{kg} \mathrm{ha}^{-1} \mathrm{y}^{-1}\right)$ & Source \\
\hline D. strictus & India & native & 4360 & Tripathi \& Singh (1995) \\
& India & native & 5900 & Tripathi \& Singh (1996) \\
Phyllostachys nigra & Japan & native & 5840 & Isagi et al. (1993) \\
$P$. pubescens & Japan & introduced & 4410 & Isagi et al. (1995) \\
\hline
\end{tabular}

reported rates for bamboos in other areas (Table 2). Typically, native LEF forest leaf fall rates are lowest during October and November (Zou et al. 1995). We found that bamboo leaf fall rates were greater than those of native forest stands for all samples collected from August to November 1996, suggesting an atypical influx of leaves to streams with riparian bamboo during a period when fewer leaves typically fell. Extreme leaf fall values measured for the $2 \mathrm{wk}$ prior to 17 September 1996 are most likely affected by the nearby passage of Hurricane Hortense.

\section{Leaf decay in streams}

A loss in diversity of leaf breakdown rates is associated with a loss in diversity of leaf species, and can result in changes to stream metabolism (Petersen \& Cummins 1974). Mass loss from leaves of bamboo and $S$. jambos followed general aquatic leaf decay patterns in that an initial period of rapid leaching was followed by more constant mass loss over time (Webster \& Benfield 1986). Linear models of decay suggest constant loss of weight over time and fit decay patterns best when macroinvertebrate processing or mechanical breakdown are minimal. Linear models, as well as the more traditional negative exponential models of aquatic decay adequately explained mass loss from leaves in our fine-mesh bag experiment. Decay rates dependent upon chemical and microbial processes alone did not differ between bamboo and $S$. jambos, although leaf chemistry and elemental release patterns did differ between the two leaf types. Bamboo leaves rapidly leached elements compared to $S$. jambos. The discrepancy may suggest that a greater proportion of the insoluble leaf structure in bamboo is unprocessed by microbes. Because a large amount of $\mathrm{C}$ is fixed per unit $\mathrm{N}$ or $\mathrm{P}$ assimilated by bamboo, their leaves are believed to be structurally complex (Soderstrom \& Calderón 1979, Tripathi \& Singh 1994).

In the presence of macro-invertebrates, leaf quality can influence mass loss (Basaguren \& Pozo 1994). Without mesh bags, decay rates of bamboo leaves were not greater than rates measured in fine-mesh bags, suggesting a minimal influence of macro-invertebrates on bamboo decay. Stream consumers may not make direct use of bamboo leaves for food. Complex internal structures in bamboo leaves may also reduce losses of leaf mass due to mechanical processing. In contrast, decay rates of $S$. jambos did increase, suggesting impacts of macro-invertebrates or leaf particle loss from mechanical processing.

We used freshly picked leaves for the decay studies, whereas naturally senesced leaves could have a significant portion of their nutrients translocated 
to culms prior to release (54-69\% of N, P and K in D. strictus; Tripathi \& Singh 1994). Regardless of nutritional quality, unless leaves are washed out by high flows, slower decay rates for bamboo suggest that bamboo leaves may provide submerged habitat structure longer than leaves of $S$. jambos or native tree species (Padgett 1976).

\section{Nutrient dynamics of leaves in streams}

By directly affecting nutrient availability and toxicity of certain ions to biota (Laskowski et al. 1995), elemental concentrations in leaves can impact the use of leaves as food and habitat. Palatability of leaves to stream consumers is dependent on a combination of conditions, including the initial nutrient status of the leaves themselves, and their level of conditioning by aquatic microbes. During terrestrial decay of bamboo in dry savannas of India, there are marked accumulations of N and P (Tripathi \& Singh 1995). During aquatic decay in the LEF, we found these nutrients to be rapidly leached from bamboo leaves. Normally, aquatic microbes attached to decomposing leaves will fix $\mathrm{N}$ from the stream water. Leaves from non-indigenous eucalyptus monocultures altered stream dynamics in headwater drainages in Portugal (Abelho \& Graça 1996). Nevertheless, during aquatic decay the eucalyptus leaves immediately accumulated $\mathrm{N}$, suggesting some amount of microbial conditioning and $\mathrm{N}$ mutabilis. We found bamboo leaves in LEF streams rapidly lose N, suggesting little or no biotic processing. Poor nutrient enrichment of leaves in streams of the LEF is unlikely to be a consequence of low elemental concentrations in the stream water, because $S$. jambos leaves in the same pools as bamboo readily accumulated $\mathrm{N}$ and other elements. In another Puerto Rico stream, Justiniano \& Betancourt (1989) report that seven aquatic fungi species were dominant in processing of $S$. jambos leaves. Unpublished data suggest different fungi species colonize bamboo (C. Betancourt, pers. comm.). Elemental increases in $S$. jambos may have resulted from stronger abilities of colonizing fungi and bacteria for active elemental uptake.

There is a net loss of $\mathrm{N}$ from the Luquillo Forest, largely attributable to dissolved organic nitrogen (DON) in streams (McDowell \& Asbury 1994). Leaf litter is an important regulator of $\mathrm{NO}_{3}{ }^{-}$through the immobilization of dissolved $\mathrm{N}$ in forest run-off. If bamboo leaves and their associated aquatic microbes cannot immobilize $\mathrm{N}, \mathrm{NO}_{3}{ }^{-}$losses may increase as bamboo spreads. Although there is a possibility that we missed $\mathrm{N}$ immobilization in bamboo leaves, this omission is unlikely. Concentrations of $\mathrm{N}$ in leaves of $S$. jambos increased after only $3 \mathrm{~d}$. After 6 wk the increase exceeded $50 \%$. Bamboo leaves had a limited immobilization of $\mathrm{N}$ by day 28 , but after $42 \mathrm{~d} \mathrm{~N}$ concentrations were still below $75 \%$ of initial concentration. There is also a net loss of $\mathrm{P}$ from the LEF (McDowell \& Asbury 1994). Concentrations of $\mathrm{P}$ in green bamboo leaves $(0.90$ $\left.\mathrm{mg} \mathrm{g}^{-1}\right)$ exceed those in green leaves of native LEF dicots $\left(0.64 \mathrm{mg} \mathrm{g}^{-1}\right)$. However, in fallen bamboo leaves, $\mathrm{P}$ concentration is lower than in native forest leaf fall. Significant amounts of nutrients (N, P and K) can be retained by 
bamboo culms prior to leaf fall (Totey et al. 1993). Bamboo may conserve $\mathrm{P}$ in this forest system by decreasing rates of $\mathrm{P}$ transfer in leaf fall to streams.

Potassium and calcium are important elements for stream macroinvertebrates, for example, in the rapid construction of chitinous exoskeletons following a molt. A rapid loss of $\mathrm{K}$ from both bamboo and $S$. jambos leaves during aquatic decay was expected because nutrients such as $\mathrm{K}$ which are not associated with leaf structure often are leached rapidly (Laskowski et al. 1995, Tripathi \& Singh 1992). However, because Ca is commonly bound in leaf structures of most plants, leaching losses would not have been expected. Bamboo leaves lost more than $75 \%$ of initial Ca concentration in the first $3 \mathrm{~d}$ of decay. Leaves of $S$. jambos however retained $\mathrm{Ca}$, with additional amounts accumulated almost immediately. Also important in influencing use or non-use of leaves by aquatic invertebrates, was a rapid increase in metals concentrations ( $\mathrm{Al}$ and $\mathrm{Fe}$ ) in bamboo leaves. Although leaves were consistently and carefully cleaned prior to analyses, potential binding of micro-fine stream sediments to decaying leaves is a natural part of the aquatic decay process and may partly explain increases in metal concentrations (F. Scatena, pers. comm.).

Introduced bamboos in riparian areas of the Luquillo Mountains may affect native stream macro-invertebrates through alteration of food resources and habitat typically provided by leaf inputs from native, mixed-species riparian forests. We found non-indigenous bamboo leaf fall exceeds that of native mixed forests, and where bamboo occurs in riparian zones, bamboo leaves undergo rapid leaching of elements during aquatic decay. We found no difference between decay rates for bamboo in the presence and absence of aquatic macroinvertebrate consumers, suggesting bamboo may not be utilized as an allocthonous food resource and negatively impacts food availability in stream pools dominated by riparian bamboo. Relatively slow rates for bamboo leaf decay suggest a considerable residency time for these leaves in stream pools, extending their potential influence on aquatic community structure. The continued downstream transport and re-rooting of broken segments of bamboo, rapid rhizome reproduction and growth, and most recently their successful flowering and seeding may accelerate bamboo expansion into currently native riparian areas. Frequent natural disturbances in the LEF are certain to influence these processes, and provide a recommended area of research into bamboo's potential impacts forest-wide. Direct comparisons of aquatic decay and nutrient loss of bamboo leaves to leaves of additional LEF riparian species are also needed. As non-indigenous bamboo expands its range in riparian areas of Puerto Rico, a decline in riparian species diversity may result in alteration of headwater stream communities dependant on a close linkage between riparian forests, and in-stream food and habitat resources.

\section{A(:KNOWIEI)(BENINTS}

This work was supported by grants IITF-96-CA-005 and IITF-97-CA-007 from the USDA Forest Service International Institute for Tropical Forestry in Río 
Piedras, Puerto Rico, as part of the NSF's Long Term Ecological Research program within the Luquillo Experimental Forest. Additional support was provided through a research scholarship from the Graduate Degree Program in Ecology at Colorado State University. Special thanks to C. Estrada, A. García, S. Moya and M. Townsend for field assistance. Many thanks also to P. Chapman for advice on statistical analyses, and to W. Clements and B. Kondratieff for helpful critiques of earlier versions of this manuscript.

\section{LITERATURE CITED}

ABELHO, M. \& GRAÇA, M. A. S. 1996. Effects of eucalyptus afforestation on leaf litter dynamics and macroinvertebrate community structure of streams in Central Portugal. Hydrobiologia 324:195-204.

BASAGUREN, A. \& POZO, J. 1994. Leaf litter processing of alder and eucalyptus in the Aguera stream system (Northern Spain): II. Macroinvertebrates associated. Archiv fuir Hydrobiologie 132:57-68.

BENSON, L. J. \& PEARSON, R. G. 1993. Litter inputs to a tropical Australian rain forest stream. Australian Journal of Ecology 18:377-383.

CHOU, C. H. 1981. Allelopathic potential of bamboo vegetation in Taiwan. XIII International Botanical Congress, Sydney, Australia, 21-28 August, 1981. Abstracts.

CHRISTIANTY, L., MAILLY, D. \& KIMMINS, J. P. 1996. 'Without bamboo, the land dies': biomass, litterfall, and soil organic matter dynamics of a Javanese bamboo talun-kebun system. Forest Ecology and Management 87:75-88.

COVICH, A. P. 1988. Geographical and historical comparisons of neotropical streams: biotic diversity and detrital processing in highly variable habitats. Journal of the North American Benthological Society 7:361-386.

COVICH, A. P., CROWL, T. A., JOHNSON, S. L. \& PYRON, M. 1996. Distribution and abundance of tropical freshwater shrimp along a stream corridor: response to disturbance. Biotropica 28:484-492.

CUMMINS, K. W., WILZBACH, M. A., GATES, D. M., PERRY, J. B. \& TALIAFERRO, W. B. 1989. Shredders and riparian vegetation. BioScience 39:24-30.

DUDGEON, D. 1994. The influence of riparian vegetation on macroinvertebrate community structure and function in six New Guinea streams. Hydrobiologia 294:65-85.

EWEL, J. J. \& WHITMORE, J. L. 1973. The ecological life zones of Puerto Rico and the United States Virgin Islands. United States Forest Service Research Paper ITF-18, Río Piedras, Puerto Rico.

FARRELLY, D. 1984. The book of bamboo. Sierra Club Books, San Francisco, USA. 332 pp.

FRIBERG, N. \& WINTERBOURN, M. J. 1997. Effects of native and exotic forest on benthic stream biota in New Zealand: a colonization study. Marine and Freshwater Research 48:267-275.

GADGIL, M. \& PRASAD, S. N. 1984. Ecological determinants of life history evolution of two Indian bamboo species. Biotropica 16:161-172.

GREGORY, S. V., SWANSON, F. J., MCKEE, W. A. \& CUMMINS, K. W. 1991. An ecosystem perspective of riparian zones. BioScience 41:540-551.

HASTINGS, A. 1996. Models of spatial spread: is the theory complete? Ecology 77:1675-1679.

IRONS, J. G., OSWOOD, M. W. \& BRYANT, J. P. 1988. Consumption of leaf detritus by a stream shredder: influence of tree species and nutrient status. Hydrobiologia 160:53-61.

ISAGI, Y., KAWAHARA, T. \& KAMO, K. 1993. Biomass and net production in a bamboo Phyllostachys bambusoides stand. Ecological Research 8:123-133.

ISAGI, Y., KAWAHARA, T. \& ITO, H. 1997. Net production and carbon cycling in a bamboo Phyllostachys pubescens stand. Plant Ecology 130:41-52.

JUSTINIANO, J. \& BETANCOURT, C. 1989. Colonización de hojas de Syzygium jambos L. por hongos ingoldianos. Caribbean Journal of Science 25:101-110.

LASKOWSKI, R., NIKLINSKA, M. \& MARYANSKI, M. 1995. The dynamics of chemical elements in forest litter. Ecology 76:1393-1406.

LODGE, D. M., SCATENA, F. N., ASBURY, C. E. \& SANCHEZ, M. J. 1991. Fine litterfall and related nutrient inputs resulting from Hurricane Hugo in subtropical wet and lower montane rainforests of Puerto Rico. Biotropica 23:336-342.

LODGE, D. M., STEIN, R. A., BROWN, K. M., COVICH, A. P., BRONMARK, C., GARVEY, J. E. \& KLOSIEWSKI, S. P. 1998. Predicting impact of freshwater exotic species on native biodiversity: challenges in spatial scaling. Australian Journal of Ecology 23:53-67.

LUGO, A. E. 1992. Comparison of tropical tree plantations with secondary forests of similar age. Ecological Monographs 62:1-41. 
LUGO, A. E. \& SCATENA, F. N. 1996. Background and catastrophic tree mortality in tropical moist, wet, and rain forests. Biotropica 28:585-599.

MCCLURE, F. A. 1993. The bamboos. (2nd edition). Smithsonian Institution Press, Washington and London. $335 \mathrm{pp}$.

MCDOWELL, W. H. \& ASBURY, C. E. 1994. Export of carbon, nitrogen, and major ions from three tropical montane watersheds. Limnology and Oceanography 39:111-125.

MOLLES, M. G., Jr. 1982. Trichopteran communities of streams associated with aspen and conifer forests: long-term structural change. Ecology 63:1-6.

MOONEY, H. A. \& DRAKE, J. A. (eds). 1986. Ecology of biological invasions of North America and Hawai'i. Ecological Studies 58. Springer-Verlag, New York. 321 pp.

NAIMAN, R. J. \& DÉCAMPS, H. 1997. The ecology of interfaces: riparian zones. Annual Review of Ecology and Systematics 28:621-658.

NUMATA, M. 1979. The relationship of limiting factors to the distribution and growth of bamboo. Pp. 258-275 in Numata, M. (ed.) Ecology of grasslands and bamboolands in the world. Dr. W. Junk bv Publishers, The Hague, The Netherlands.

O'CONNOR, P. J. 1998. Habitat selection in insular tropical streams: macroinvertebrate responses to a riparian invasion by non-indigenous bamboos. MSc Thesis, Colorado State University, Ft. Collins, CO, USA. 154 pp.

PADGETT, D. E. 1976. Leaf decomposition by fungi in a tropical rain forest stream. Biotropica 8:166178.

PETERSEN, R. C. \& CUMMINS, K. W. 1974. Leaf processing in a woodland stream. Freshwater Biology $4: 343-368$.

PIMM, S. L., RUSSELL G. J., GITTLEMAN, J. L. \& BROOKS, T. M. 1995. The future of biodiversity. Science 269:347-350.

REAGAN, D. P. \& WAIDE, R. B. (eds). 1996. The food web of a tropical rain forest. University of Chicago Press, Chicago. 616 pp.

RUESINK, J. L., PARKER, I. M., GROOM, M. J. \& KAREIVA, P. M. 1995. Reducing the risks of non-indigenous species introductions. BioScience 45:465-477.

SAS 1996. Statistical software. Release 6.12, Windows version 4. The SAS Institute, Cary, North Carolina, USA.

SCATENA, F. N. \& LARSEN M. C. 1991. Physical aspects of hurricane damage in Puerto Rico. Biotropica 23:317-323.

SCATENA, F. N. \& LUGO A. E. 1995. Geomorphology, disturbance, and the soil and vegetation of two subtropical wet steepland watersheds of Puerto Rico. Geomorphology 13:199-213.

SCATENA, F. N., MOYA, S., ESTRADA, C. \& CHINEA, J. D. 1996. The first five years in the reorganization of aboveground biomass and nutrient use following Hurricane Hugo in the Bisley Experimental Watersheds, Luquillo Experimental Forest, Puerto Rico. Biotropica 28:424-440.

SODERSTROM, T. R. \& CALDERÓN, C. E. 1979. Distribution and enviromment of the Bambusiodeae. Pp. 224-236 in Numata, M. (ed.) Ecology of grasslands and bamboolands in the world. Dr. W. Junk bv Publishers, The Hague, The Netherlands.

TAYLOR, A. H., QIN, Z. \& LIU, J. 1996. Structure and dynamics of subalpine forests in the Wang Lang Natural Preserve, Sichuan, China. Vegetatio 124:25-38.

TOTEY, N. G., BHOWMIK, A. K., KHATRI, A. K. \& BANERJEE, S. K. 1993. Litterfall and nutrient dynamics in soil under bamboo (Dendrocalamus strictus). Indian Agriculturalist 37:89-97.

TRIPATHI, S. K. \& SINGH, K. P. 1992. Abiotic and litter quality control during the decomposition of different plant parts in dry tropical bamboo savanna in India. Pedobiologia 36:241-256.

TRIPATHI, S. K. \& SINGH, K. P. 1994. Productivity and nutrient cycling in recently harvested and mature bamboo savannas in the dry tropics. Journal of Applied Ecology 31:109-124.

TRIPATHI, S. K. \& SINGH, K. P. 1995. Litter dynamics of recently harvested and mature bamboo savannas in a dry tropical region in India. Journal of Tropical Ecology 11:403-417.

TRIPATHI, S. K. \& SINGH, K. P. 1996. Culm recruitment, dry matter dynamics and carbon flux in recently harvested and mature bamboo savannas in the Indian dry tropics. Ecological Research 11:149164.

VANNOTE, R. L., MINSHALL, G. W., CuMMINS, K. W., SEDELl, J. R. \& CUSHING, C. E. 1980. The river continuum concept. Cianadian Journal of Fisheries and Aquatic Sciences 37:130-137.

VITOUSEK, P. M. 1986. Biological invasions and ecosystem properties: can species make a difference? Pp. 434-459 in Mooney, H. A. \& Drake, J. A. (eds). Ecology of biological intasions of North America and Hawai'i. Springer-Verlag, New York.

VITOUSEK, P. M. 1990. Biological invasions and ecosystem processes: towards an integration of population biology and ecosystem studies. Oikos 57:247-265.

VITOUSEK, P. M., D'ANTONIO, C. M., LOOPE, L. L. \& WESTBROOKS, R. 1996. Biological invasions as global environmental change. American Scientist 84:468-477. 
WALLACE, J. B., EGGERT, S. L., MEYER, J. L. \& WEBSTER, J. R. 1997. Multiple trophic levels of a forest stream linked to terrestrial litter inputs. Science 277:102-104.

WEBSTER, J. R. \& BENFIELD, E. F. 1986. Vascular plant breakdown in freshwater ecosystems. Annual Review of Ecology and Systematics 17:567-594.

WHITE, D. G. \& CHILDERS, N. F. 1945. Bamboo for controlling soil erosion. Journal of the American Society of Agronomy 37:839-847.

ZOU, X., ZUCCA, C. P., WAIDE, R. B. \& MCDOWELL, W. H. 1995. Long-term influence of deforestation on tree species composition and litter dynamics of a tropical rain forest in Puerto Rico. Forest Ecology and Management 78:147-157. 